\title{
First-Line Enlisted Military Supervisor and Managers
}

National Cancer Institute

\section{Source}

National Cancer Institute. First-Line Enlisted Military Supervisor and Managers. NCI

Thesaurus. Code C122454.

Workers who directly supervise and coordinate the activities of enlisted military personnel. 